\title{
KEBERADAAN MIKROBA PADA BAKSO IKAN ASAP CAIR, YANG DIKEMAS DALAM RETORTABLE POUCH, DIPASTEURISASI DAN DISIMPAN PADA TEMPERATUR RUANG
}

\author{
Margani Luyuani Rohana ${ }^{1}$, S. Berhimpon ${ }^{2}$ dan Joyce V. Palenewen ${ }^{2}$ \\ 1) Mahasiswa pada Program Studi Teknologi Hasil Perikanan FPIK Unsrat Manado \\ 2) Staf pengajar pada Program Studi Teknologi Hasil Perikanan FPIK Unsrat Manado \\ Email: marganiluyuanirohana@yahoo.com
}

\begin{abstract}
A research has been done to assess the presence of microbes and the shelf life of fish balls dipped in liquid smoke, packed in retortable pouch, pasteurized, and stored at room temperature. The method used in this research is an experimental method that revealed the facts based on existing problems through hypothesis testing. Parameters assessed are Total Plate Count (TPC), total Salmonella, total coliforms and E. coli, total vibrio, water content, and $\mathrm{pH}$. Fish balls were pasteurized in $85^{\circ} \mathrm{C}$ and stored in room temperature for $0,3,6$, and 9 days, and were pasteurized at $100^{\circ} \mathrm{C}$ and storage in room temperature for $0,9,18$, and 27 days. The results shown that all pathogen were negative, but based on Indonesian standard (SNI 01-7266-1-2006) especially TPC value, fish balls were packaged in retortable pouch and without pasteurized is no longer acceptable for consumption after 3 days of storage, and fish balls were packaged in retortable pouch and pasteurized at $85^{\circ} \mathrm{C}$ no longer acceptable for consumed after 6 days of storage. While the fish balls are packaged in retortable pouch and pasteurized at $100^{\circ} \mathrm{C}$ is no longer acceptable for consumed after 18 days of storage.
\end{abstract}

\begin{abstract}
Keyword: Retortable Pouch, Pasteurization, Pathogens.
Penelitian ini bertujuan untuk mengetahui keberadaan mikroba dan daya awet bakso ikan yang direndam dalam asap cair dan dikemas dalam Retortable pouch, dipasteurisasi, dan disimpan pada temperatur ruang. Metode yang digunakan dalam penelitian ini adalah metode eksperimen untuk menguji hipotesa. Parameter yang diamati yaitu Angka Lempeng Total (ALT), Salmonella, total koliform dan E.coli, total vibrio, analisa kadar air, dan nilai $\mathrm{pH}$. Bakso ikan asap cair yang dipasteurisasi pada $85^{\circ} \mathrm{C}$, disimpan pada temperatur ruang selama $0,3,6$, dan 9 hari, dan yang dipasteurisasi pada $100^{\circ} \mathrm{C}$, disimpan pada temperatur ruang selama $0,9,18$, dan 27 hari. Hasil penelitian menunjukkan bahwa bakso ikan yang dikemas dalam Retortable pouch, tanpa dipasteurisasi sudah tidak layak lagi untuk dikonsumsi setelah penyimpanan 3 hari, dan bakso ikan yang dikemas dalam Retortable pouch dan dipasteurisasi pada $85^{\circ} \mathrm{C}$ sudah tidak layak lagi untuk dikonsumsi setelah penyimpanan 6 hari. Bakso ikan yang dikemas dalam Retortable pouch, dan dipasteurisasi pada $100^{\circ} \mathrm{C}$ nanti tidak layak lagi dikonsumsi setelah penyimpanan 18 hari.
\end{abstract}

Kata Kunci: Kemasan Retortable Pouch, Pasteurisasi, Patogen.

\section{PENDAHULUAN}

Bakso adalah makanan yang sangat digemari oleh masyarakat Indonesia, karena rasanya enak dan dapat dimakan oleh berbagai kalangan masyarakat dari anak-anak, remaja sampai dewasa. Namun di zaman yang semakin modern ini bakso yang pada umumnya terbuat dari daging sapi dimodifikasi menggunakan daging ikan agar dapat dikonsumsi oleh konsumen dari semua golongan agama. Selain itu daging ikan kaya akan protein, sedikit lemak dan harganya lebih murah dibanding daging sapi. Namun demikian, bakso dari daging ikan lebih cepat membusuk dibandingkan dengan dari daging sapi, karena daging ikan memiliki kandungan air yang cukup tinggi dan jaringan ikat yang rendah, sehingga daya awet bakso daging ikan pada temperatur ruang hanya satu hari. Para pedagang yang menjual bakso ikan sangat khawatir akan dagangannya yang tidak habis terjual karena bakso yang tidak terjual harus dibuang. Oleh karena itu dibutuhkan cara pengawetan yang tepat untuk bakso ikan, karena banyak pedagang-pedagang yang curang, dimana bakso ikan diawetkan dengan menggunakan boraks serta formalin, dimana bahan kimia tersebut sangat membahayakan 
kesehatan manusia. Pengawetan bakso ikan dapat juga dengan cara penyimpanan pada temperatur dingin atau pembekuan, tetapi cara tersebut mahal. Akhir-akhir ini, penggunaan asap cair dalam mengawetkan ikan telah semakin banyak diteliti karena dapat memberikan citarasa yang diinginkan dan dapat menghambat pertumbuhan bakteri patogen serta aman untuk dikonsumsi. Pengasapan ikan merupakan metode pengawetan yang memberikan citarasa serta warna yang khas terhadap produk, dan dapat meningkatkan daya awet.

Pada penelitian ini bakso ikan direndam dengan asap cair, dikemas vakum dalam Retortable pouch, agar dapat dipasteurisasi dan membunuh bakteri patogen.

\section{METODOLOGI PENELITIAN}

Metode yang digunakan dalam penelitian adalah metode eksperimen yaitu mengungkapkan fakta-fakta berdasarkan permasalahan yang ada melalui pengujian hipotesa. Gay (1981), menyatakan bahwa metode penelitian eksperimental merupakan satu-satunya metode penelitian yang dapat menguji secara benar hipotesis menyangkut hubungan kausal (sebab akibat).

\section{Tempat dan Waktu Pelaksanaan Penelitian}

Pelaksanaan penelitian dilakukan di

Laboratorium Teknolgi Pengendalian Mutu Hasil Perikanan, dan Penanganan dan Pengolahan Hasil Perikanan, Fakultas Perikanan dan Ilmu Kelautan Universitas Sam Ratulangi Manado. Penelitian dilaksanakan selama 2 bulan, yaitu April-Juni 2016.

\section{Alat dan Bahan}

Alat yang digunakan dalam penelitian ini yaitu tabung reaksi, pipet, erlemeyer, autoclave, tabung hach (durham), petridis, gelas ukur, spatula, beaker gelas, cawan porselin, oven, penjepit cawan porselin, timbangan analitik, pH meter, kompor gas, dandang, baki, keranjang, thermocouple, timer, lemari penyimpanan, mesin vakum.

Bahan yang digunakan yaitu bakso Mutiara Paal Dua, kemasan tahan panas Retortable pouch, asap cair 0,8\%, alkohol, akuades, $\mathrm{NaCl}(0,9 \%)$, media Nutrient Agar (NA), media Bismuth sulfith agar (BSA), media EC Broth, media Alkaline Peptone Water (APW), Thiosulphate Citrate BileSalts Sucrose
Agar (TCBS Agar), Eosin Methylene Blue Agar (EMB Agar), larutan buffer $\mathrm{pH} 4$ dan $\mathrm{pH} 7$, kertas label.

\section{Hipotesa}

Ho: Pasteurisasi dan lama penyimpanan tidak berpengaruh nyata terhadap keberadaan mikroba dan daya awet bakso ikan.

H1: Pasteurisasi dan lama penyimpanan berpengaruh nyata terhadap keberadaan mikroba dan daya awet bakso ikan.

\section{Perlakuan dan Rancangan Percobaan \\ Bakso yang dipasteurisasi pada $85^{\circ} \mathrm{C}$}

Perlakuan A: Pasteurisasi

A1: Dikemas dalam Retortable pouch, tanpa dipasteurisasi

A2: Dikemas dalam Retortable pouch, dan dipasteurisasi pada $85^{\circ} \mathrm{C}$

Perlakuan B: Penyimpanan produk pada

B1: 0 hari temperatur ruang

B2: 3 hari

B3: 6 hari

B4: 9 hari

\section{Bakso yang dipasteurisasi pada $100^{\circ} \mathrm{C}$}

Perlakuan A: Pasteurisasi

A1: Dikemas dalam Retortable pouch, tanpa dipasteurisasi

A2: Dikemas dalam Retortable pouch, dan dipasteurisasi pada $100^{\circ} \mathrm{C}$

Perlakuan B: Penyimpanan produk pada temperatur ruang

B1: 0 hari

B2: 9 hari

B3: 18 hari

B4: 27 hari

\section{Rancangan Percobaan}

Rancangan percobaan yang digunakan adalah Rancangan Acak Lengkap (RAL) yang disusun secara faktorial $2 \times 4$ dengan dua ulangan, baik untuk yang dipasteurisasi $85^{\circ} \mathrm{C}$, maupun yang dipasteurisasi $100^{\circ} \mathrm{C}$. Uji Beda Nyata Terkecil (BNT) digunakan untuk membedakan perlakuan yang nyata pada uji annova.

\section{TATA LAKSANA PENELITIAN}

Sampel yang digunakan dalam penelitian ini adalah bakso ikan yang dibeli di rumah makan Mutiara Paal Dua. Bakso dalam 
kemasan Mutiara Paal Dua, dikeluarkan dan direndam dengan larutan asap cair $0,8 \%$ dengan perbandingan 1:2 (b/v) selama 30 menit, selanjutnya bakso ditiriskan menggunakan baki atau keranjang, dalam lemari penyimpanan selama 5 menit untuk menghindari kontaminasi silang. Setelah penirisan, bakso dimasukkan ke dalam kemasan Retortable pouch sebanyak empat bakso dalam satu kemasan kemudian, divakum menggunakan mesin vakum merek powerpack. Bakso ikan yang sudah dikemas vakum disortir atau dipisahkan menurut perlakuan yaitu tanpa dipasteurisasi, dipasteurisasi pada $85^{\circ} \mathrm{C}$, dan dipasteurisasi pada $100^{\circ} \mathrm{C}$. Bakso ikan yang tidak dipasteurisasi disimpan pada lemari penyimpanan terlebih dahulu. Air didihkan lalu diukur temperatur $85^{\circ} \mathrm{C}$ menggunakan thermocouple kemudian sampel bakso ikan yang sudah dikemas vakum dimasukkan ke dalam panci secara terpisah, kemudian temperatur dipertahankan $85^{\circ} \mathrm{C}$ selama 60 menit. Selanjutnya dilakukan perlakuan yang sama pada temperatur $100^{\circ} \mathrm{C}$. Setelah dipasteurisasi sampel diangkat lalu dicelupkan pada air yang diberi es dengan temperatur $5^{\circ} \mathrm{C}$ yang sudah disiapkan untuk mendinginkan dan untuk membunuh bakteri termofilik. Kemudian sampel diberi kode sesuai dengan perlakuan masing-masing. Selanjutnya disimpan pada lemari penyimpanan temperatur ruang.

\section{HASIL DAN PEMBAHASAN}

Keberadaan Mikroba, Kadar Air, Dan pH Bakso ikan yang dipasteurisasi pada $85^{\circ} \mathrm{C}$. Angka Lempeng Total (ALT)

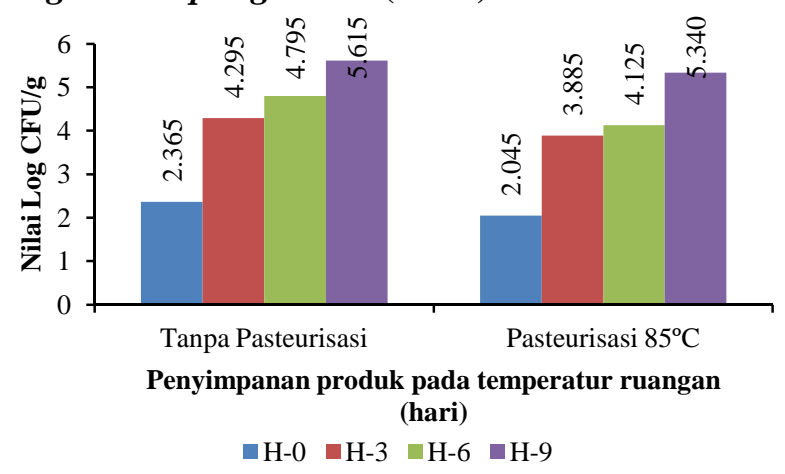

Gambar 1. Histogram ALT bakso ikan tanpa dipasteurisasi dan dipasteurisasi $85^{\circ} \mathrm{C}$ dan disimpan pada temperatur ruang.
Analisis keragaman ALT menunjukkan bahwa pasteurisasi pada $85^{\circ} \mathrm{C}$, dan penyimpanan produk pada temperatur ruang berpengaruh sangat nyata $(\mathrm{P}>0,01)$ (Gambar 1$)$.

Gambar 1 menunjukkan bahwa bakso ikan yang dikemas dalam Retortable pouch tanpa dipasteurisasi mempunyai kandungan bakteri yang lebih banyak dibandingkan dengan bakso ikan yang dikemas dalam Retortable pouch dan dipasteurisasi pada $85^{\circ} \mathrm{C}$. Zuraida, $d k k$. (2009), menyatakan bahwa bakso ikan yang diberi asap cair dan dikontrol secara visual, sudah terbentuk lendir. Terbentuknya lendir mengindikasikan bahwa produk tersebut mengalami kemunduran mutu akibat aktivitas bakteri, sehingga sebaiknya tidak dikonsumsi lagi (Kok, Park 2007; Siskos et.al., 2007). Aktivitas mikroba juga dipengaruhi oleh penyimpanan, dimana semakin lama penyimpanan produk maka jumlah bakteri semakin meningkat. Hal ini diperkuat oleh Berhimpon (1995), bahwa meningkatnya jumlah koloni bakteri berhubungan dengan meningkatnya nilai $\mathrm{pH}$ selama penyimpanan. Temperatur ruang penyimpanan produk 25$30^{\circ} \mathrm{C}$ juga cocok untuk pertumbuhan mikroba.

Berdasarkan persyaratan mutu yang dikeluarkan oleh Badan Standarisasi Nasional Indonesia (SNI 01-7266.1-2006) bahwa jumlah bakteri maksimum $5,0 \times 10^{4} \mathrm{CFU} / \mathrm{g}$, hal ini berarti jumlah bakteri pada bakso ikan dengan perlakuan tanpa dipasteurisasi sudah melebihi SNI setelah penyimpanan 3 hari pada temperatur ruang, sehingga sudah tidak layak lagi untuk dikonsumsi. Sedangkan dengan perlakuan dipasteurisasi pada $85^{\circ} \mathrm{C}$ tidak layak untuk dikonsumsi, setelah penyimpanan 6 hari pada temperatur ruang.

\section{Salmonella, Total Koliform, E. coli, dan Total Vibrio}

Hasil pengamatan menunjukkan bahwa Salmonella, total koliform, E. coli, dan total Vibrio, pada bakso ikan yang dikemas dalam Retortable pouch tanpa dipasteurisasi, dan yang dipasteurisasi pada $85^{\circ} \mathrm{C}$, adalah negatif. Hal ini menunjukkan bahwa bakso yang dipakai sebagai bahan penelitian cukup baik karena walaupun tidak dipasteurisasi hasil uji Salmonella adalah negatif, hal ini berarti pengolahan pada bakso ikan dilakukan secara tepat dengan sanitasi dan higienis tetap terjaga.

SNI 01-7266-1-2006 mensyaratkan Salmonella dan total Vibrio harus negatif, dan 
E. coli maksimal<3,6 APM/g, namun demikian, karena selain pathogen, SNI 01-7266-1-2006 juga mencantumkan nilai ALT sebagai kelayakan untuk dikonsumsi, maka dengan demikian untuk perlakuan tanpa pasteurisasi hanya layak dikonsumsi sampai dengan penyimpanan 3 hari, dan perlakuan dipasteurisasi $85^{\circ} \mathrm{C}$ layak sampai penyimpanan 6 hari, pada temperatur ruang.

\section{Kadar Air}

Hasil analisis keragaman kadar air menunjukkan bahwa pasteurisasi, dan penyimpanan produk pada temperatur ruang, serta interaksi kedua perlakuan tidak berpengaruh nyata terhadap keberadaan mikroba pada bakso ikan $(\mathrm{P}<0,05)$. Nilai kadar air pada bakso ikan setelah perlakuan, dapat dilihat pada Gambar 2.

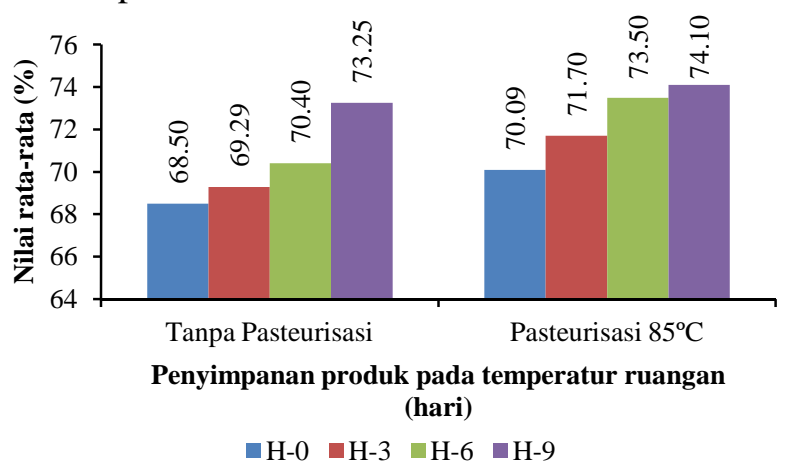

Gambar 2. Histogram kadar air bakso ikan tanpa dipasteurisasi dan dipasteurisasi $85^{\circ} \mathrm{C}$ dan disimpan pada temperatur ruang.

Gambar 2 menunjukkan bahwa bakso ikan yang dikemas dalam Retortable pouch tanpa dipasteurisasi cenderung mempunyai nilai rata-rata kadar air lebih sedikit dibandingkan dengan bakso ikan yang dikemas dalam Retortable pouch dipasteurisasi pada $85^{\circ} \mathrm{C}$, namun secara statistik kadar air bakso ikan tanpa pasteurisasi tidak berbeda nyata dengan yang dipasteurisasi $85^{\circ} \mathrm{C}$. Purnomo (1996), bahwa suhu dan kelembaban tempat peyimpanan mempengaruhi kenaikan kadar air, karena produk selama penyimpanan seimbang dengan kelembapan sekitarnya. Hal ini juga dinyatakan oleh Sikorski (1990), peningkatan kadar air pada bakso ikan selama penyimpanan disebabkan oleh aktivitas bakteri proteolitik, sehingga protein terdenaturasi dan kehilangan kemampuan mengikat air.

\section{Analisa nilai $\mathbf{p H}$}

Hasil analisis keragaman nilai $\mathrm{pH}$ menunjukkan bahwa pasteurisasi tidak berpengaruh nyata, dan penyimpanan produk pada temperatur ruang berpengaruh sangat nyata $(\mathrm{P}>0,01)$, tetapi interaksi kedua perlakuan tidak berpengaruh nyata terhadap keberadaan mikroba pada bakso ikan $(\mathrm{P}<0,05)$. Nilai $\mathrm{pH}$ pada bakso ikan setelah perlakuan, dapat dilihat pada Gambar 3.

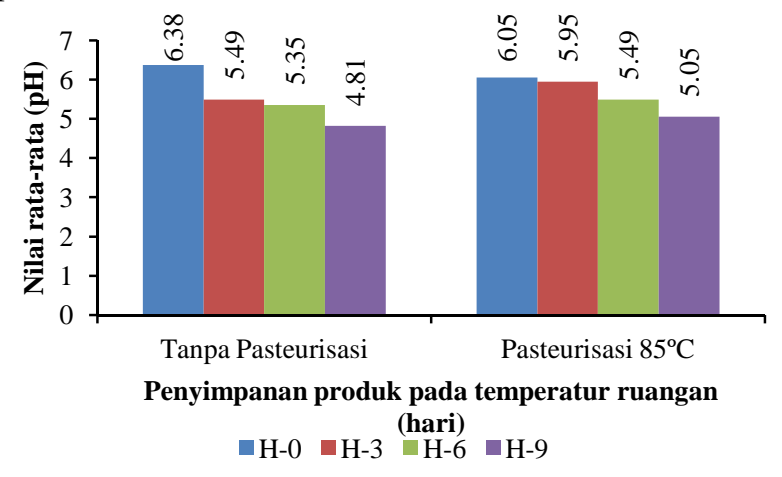

Gambar 3. Histogram pH bakso ikan tanpa dipasteurisasi dan dipasteurisasi $85^{\circ} \mathrm{C}$ dan disimpan pada temperatur ruang.

Gambar 3 menunjukkan bahwa nilai $\mathrm{pH}$ pada bakso ikan selama 0, 3, 6, dan 9 hari penyimpanan cenderung mengalami penurunan. Menurut Muratore et.al. (2007), penurunan nilai $\mathrm{pH}$ disebabkan oleh metabolisme bakteri asam laktat. Pendapat tersebut didukung oleh Sthor et.al. (2001), yang menyatakan bahwa bakteri asam laktat merupakan penyebab utama penguraian kandungan gizi produk pengasapan. Hal ini didukung juga oleh nilai ALT yang semakin meningkat. Kenaikan $\mathrm{pH}$ sepertinya tidak mungkin, karena bakso dikemas vakum, sehingga tidak terjadi penguapan senyawasenyawa asap. Menurut Berhimpon (1995) $\mathrm{pH}$ produk yang semakin meningkat karena selama penyimpanan terjadi penguapan senyawasenyawa asap dan pengawet penting sehingga $\mathrm{pH}$ produk meningkat.

\section{Bakso Ikan Yang Dipasteurisasi Pada $100^{\circ} \mathrm{C}$ Analisa Angka Lempeng Total (ALT) \\ Hasil analisis keragaman ALT menunjukkan bahwa pasteurisasi dan penyimpanan produk pada temperatur ruangan, serta interaksi kedua perlakuan berpengaruh sangat nyata terhadap keberadaan mikroba pada bakso ikan $(\mathrm{P}>0,01)$. Keberadaan ALT pada}


bakso ikan setelah perlakuan, dapat dilihat pada Gambar 4.

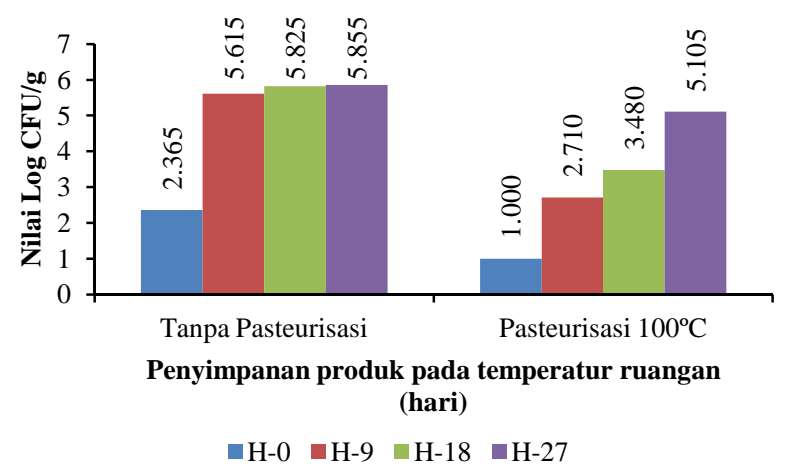

Gambar 4. Histogram ALT bakso ikan tanpa dipasteurisasi dan dipasteurisasi $100^{\circ} \mathrm{C}$ dan disimpan pada temperatur ruang.

Gambar 4 menunjukkan bahwa bakso ikan yang dikemas dalam Retortable pouch tanpa dipasteurisasi mempunyai kandungan bakteri yang lebih banyak dibandingkan dengan bakso ikan yang dikemas dalam Retortable pouch dan dipasteurisasi pada $100^{\circ} \mathrm{C}$. Namun pada penyimpanan 9, 18 dan 27 hari pada perlakuan tanpa pasteurisasi memiliki kandungan bakteri yang tidak berbeda jauh, hal ini dinyatakan oleh Fatkan (2009), bahwa kemampuan mikroorganisme untuk tumbuh dapat melakukan aktivitas enzimatis yang dipengaruhi oleh temperatur dan lama penyimpanan.

Berdasarkan persyaratan mutu yang dikeluarkan oleh Badan Standarisasi Nasional Indonesia (SNI 01-7266.1-2006) bahwa jumlah bakteri maksimum $5,0 \times 10^{4} \mathrm{CFU} / \mathrm{g}$, hal ini berarti jumlah bakteri pada bakso ikan dengan perlakuan tanpa dipasteurisasi sudah melebihi SNI setelah penyimpanan 3 hari pada temperatur ruang, sehingga sudah tidak layak lagi untuk dikonsumsi. Sedangkan dengan perlakuan dipasteurisasi pada $100^{\circ} \mathrm{C}$ masih layak untuk dikonsumsi, sampai penyimpanan 18 hari pada temperatur ruang.

Salmonella, Total Koliform, E. Coli, dan Total Vibrio

Hasil pengamatan menunjukkan bahwa Salmonella, total koliform dan E. coli, Serta total Vibrio, pada bakso ikan yang dikemas dalam Retortable pouch tanpa dipasteurisasi, dan yang dipasteurisasi pada $100^{\circ} \mathrm{C}$, adalah negatif. Hal ini menunjukkan bahwa bakso yang dipakai sebagai bahan penelitian cukup baik karena walaupun tidak dipasteurisasi hasil uji Salmonella adalah negatif, hal ini berarti pengolahan pada bakso ikan dilakukan secara tepat dengan sanitasi dan higienis tetap terjaga.

SNI 01-7266-1-2006 mensyaratkan Salmonella dan total Vibrio harus negatif, dan E. coli maksimal <3,6 APM/gr, namun demikian, karena selain pathogen, SNI 017266-1-2006 juga mencantumkan nilai ALT sebagai kelayakan untuk dikonsumsi, maka dengan demikian untuk perlakuan tanpa pasteurisasi hanya layak dikonsumsi sampai dengan penyimpanan 3 hari, dan perlakuan dipasteurisasi $100^{\circ} \mathrm{C}$ bakso ikan masih layak sampai penyimpanan 18 hari.

\section{Kadar air}

Hasil analisis keragaman kadar air menunjukkan bahwa pasteurisasi, dan penyimpanan produk pada temperatur ruang, serta interaksi kedua perlakuan tidak berpengaruh nyata terhadap keberadaan mikroba pada bakso ikan. $(\mathrm{P}<0,05)$. Nilai kadar air pada bakso ikan setelah perlakuan, dapat dilihat pada Gambar 5.

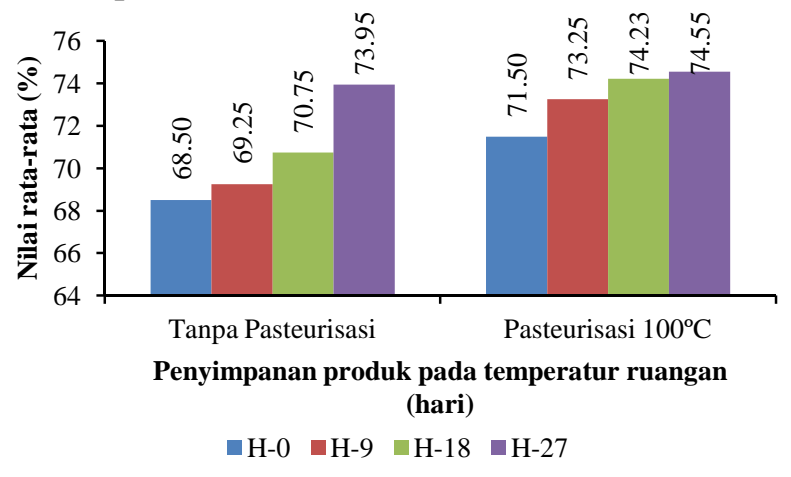

Gambar 5. Histogram kadar air bakso ikan tanpa dipasteurisasi dan dipasteurisasi $100{ }^{\circ} \mathrm{C}$ dan disimpan pada temperatur ruang.

Gambar 5 menunjukkan bahwa bakso ikan yang dikemas dalam Retortable pouch tanpa dipasteurisasi nilai rata-rata kadar air lebih sedikit dibandingkan dengan bakso ikan yang dikemas dalam Retortable pouch dipasteurisasi pada $100^{\circ} \mathrm{C}$, namun secara statistik kadar air bakso ikan tanpa pasteurisasi tidak berbeda nyata dengan yang dipasteurisasi $100^{\circ} \mathrm{C}$. Menurut buckle, $d k k .1987$ bahwa pengaruh kadar air sangat penting sekali dalam menentukan daya awet suatu bahan pangan karena kadar air mempengaruhi siat-sifat fisik (organoleptik, sifak kimia dan kebusukan oleh 
mikroorganisme. Peningkatan kadar air juga dapat diakibatkan oleh penguapan, ketika penguapan kadar air pada ikan, uap air tidak dapat keluar dan terkurung dalam plastik sehingga mengembun dan membentuk butiran air dan terserap kembali oleh ikan asap dalam kemasan plastik. Hal ini menyebabkan meningkatnya kadar air pada bakso ikan (Anonimous, 2013).

\section{Analisa Nilai pH}

Hasil analisis keragaman nilai $\mathrm{pH}$ menunjukkan bahwa pasteurisasi berpengaruh sangat nyata, dan penyimpanan produk pada temperatur ruang berpengaruh nyata, serta interaksi kedua perlakuan berpengaruh sangat nyata terhadap keberadaan mikroba pada bakso ikan $(\mathrm{P}>0,01)$. Nilai $\mathrm{pH}$ pada bakso ikan setelah perlakuan, dapat dilihat pada Gambar 6 .

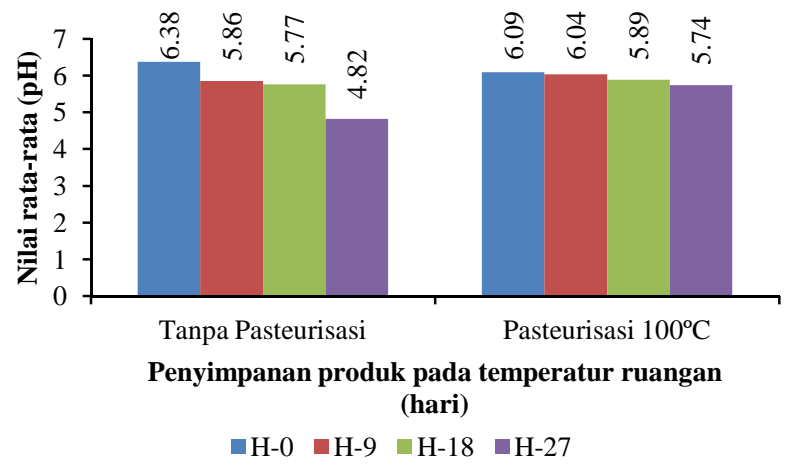

Gambar 6. Histogram pH bakso ikan tanpa dipasteurisasi dan dipasteurisasi $100^{\circ} \mathrm{C}$ dan disimpan pada temperatur ruang.

Gambar 6 menunjukkan bahwa nilai $\mathrm{pH}$ pada bakso ikan selama $0,9,18$, dan 27 hari penyimpanan cenderung mengalami penurunan pada produk. dapat dilihat bahwa nilai $\mathrm{pH}$ pada perlakuan tanpa dipasteurisasi cenderung lebih rendah dibandingkan dengan perlakuan dipasteurisasi $100^{\circ} \mathrm{C}$. Hal ini disebabkan oleh adanya aktivitas metabolisme mikroba cepat, sehingga $\mathrm{pH}$ bakso mengalami penurunan (Fitrianto, dkk. 2014). Varnam dan Sutherland (1995), juga menyatakan bahwa penurunan $\mathrm{pH}$ disebabkan karena adanya bakteri asam laktat alami dalam bakso yang mampu melakukan aktivitas fermentasi dalam mengubah glikogen dan menghasilkan asam laktat. Purnomo (1997), menambahkan bahwa setiap mikroorganisme mempunyai kisaran $\mathrm{pH}$ dimana pertumbuhan masih memungkinkan dan masing-masing biasanya mempunyai $\mathrm{pH}$ optimum. Beberapa mikroorganisme dalam bahan pangan tertentu seperti khamir dan bakteri asam laktat tumbuh dengan baik kisaran nilai $\mathrm{pH}$ 3,0-6,0.

\section{KESIMPULAN}

Nilai ALT bakso ikan yang dikemas dalam Retortable pouch dan tanpa dipasteurisasi pada 0 hari: $2,0 \times 10^{2}$ dan meningkat menjadi $5,6 \times 10^{5}$ pada penyimpanan 9 hari pada temperatur ruang, nilai ALT bakso ikan yang dikemas dalam Retortable pouch dan dipasteurisasi pada $85^{\circ} \mathrm{C}$ pada 0 hari: $1,4 \times 10^{2}$ dan meningkat menjadi $2,3 \times 10^{5}$ pada penyimpanan 9 hari pada temperatur ruang, dan bakso ikan yang dikemas dalam Retortable pouch dan dipasteurisasi pada $100^{\circ} \mathrm{C}$ pada 0 hari: $1,0 \times 10^{2}$ dan meningkat menjadi $1,9 \times 10^{5}$ pada penyimpanan 27 hari pada temperatur ruang.

Bakteri patogen Salmonella, total koliform dan E. coli, serta total vibrio adalah negatif, baik pada bakso ikan yang tanpa dipasteurisasi maupun dipasteurisasi $85^{\circ} \mathrm{C}$ dan $100^{\circ} \mathrm{C}$, walaupun demikian, berdasarkan hasil pengamatan ALT bahwa bakso ikan yang dikemas dalam Retortable pouch dan tanpa dipasteurisasi hanya layak untuk dikonsumsi sampai penyimpanan 3 hari, dan bakso ikan yang dipasteurisasi $85^{\circ} \mathrm{C}$ masih layak luntuk dikonsumsi setelah penyimpanan 6 hari, sedangkan bakso ikan yang dipasteurisasi pada $100^{\circ} \mathrm{C}$ masih layak dikonsumsi sampai pada penyimpanan 18 hari.

\section{DAFTAR PUSTAKA}

Anonimous, 2013. Manfaat Bakso Ikan. http://www. keripik-casciscus .com /2013 /07/ manfaat-baksoikan.html. Diakses tanggal 10 Mei 2016

Badan Standarisasi Nasional (BSN). 2006. SNI 012354.2-2006 Penentuan Kadar Air Produk Perikanan. Jakarta : Badan Standarisasi Nasional.

Buckle. K.A., R.A. Edward., G.H., Fleet., M Wooten. 1987. Ilmu pangan. Penerjemah hari purnomo dan adiono. UI-Press. Jakarta.

Berhimpon, S. 1995. Studi Pengemasan Dan Penyimpanan Ikan Asap Dan Produk Olahannya. Penelitian Mandiri. Fakultas Perikanan. UNSRAT. Manado.

Fardiaz, D., A. Aprianto., S. Yasni., S. Budayanto. 1986. Penuntun praktikum Analisa Pangan. Jurusan teknologi pangan dan gizi. Fakultas teknologi pertanian IPB. Bogor.

Fatkhan R. 2009. Hubungan Antara Jumlah Total Bakteri Dan Angka Katalase Terhadap Daya Tahan Susu. Institut Pertanian Bogor. Bogor 
Fitrianto E., Rosyidi D., Thohari I. 2014. Pengaruh Lama Simpan Terhadapa Kualitas Uji Mikrobiologi Bakso daging kalkun. Fakultas Peternakan. Unbraw. Malang.

Gay, L. R. 1981. Educational Research: Competencies for Anlysis and Application. London: Prentice-Hall International (UK) ltd.http:// www. eurekapendidikan.com /2015/11/metode-penelitianeksperimen.html. Diakses pada tanggal 10 Mei 2016.

Hadiyanti R.M., Wikandari R.P. 2013. Pengaruh Konsentrasi Dan Penambahan Bakteri Asam Laktat Lactobacillus Plantarum B1765 Sebagai Kultur Starter Terhadap Mutu Produk Bekasam Bandeng (Chanos Chanos). UNESA Journal of Chemistry 2(3). Surabaya.

Ishak, E. dan Amrullah. 1985. Ilmu dan TeknologiPangan. Badan Kerja Sama. Perguruan Tinggi Negeri Indonesia Bagian Timur Manado.

Kok,T.N., Park,J.W. 2007. Extending the Shelf Life of Set Fish Ball. J of Food Quality 30(1)-27.

Muratore G., Mazzaglia A., Lanza CM., Licciardello F. 2007. Process Variables On The Quality Of Swordfish Fillets Flavored With Smoke Condensate. J Food Proc And Preserv 31:167-177.

Moeljanto. 1992. Pengawetan dan Pengolahan Hasil Perikanan. Penebar Swadaya. Jakarta.
Purnomo.H. 1995. Aktivitas Air dan Peranannya Dalam Pengawetan Pangan. UI-Press. Malang.

Purnomo, H. 1997. Pengaruh Subtitusi Tepung Dan Tepung Kedelai terhadap Kualitas Bakso. Agrivita. 20 (3) : 138-141. Jakarta.

Siskos I., Zotos A., Melidos S., Tsikritzi R. 2007. The Effect Of Liquid Smoking Of Fillets Of Trout (Salmo Gairdrerii) On Sensory, Mikrobiological And Chemical Changes During Chilled Storage. Food Chem 101:458-464.

Sikorski,Z.E. 1990. Seafood: Resources, Nutritional Composistion, and Preservation. Boca Raton, Florida: CRC Pr.

Stohr V, Jofffraud JJ, Cardinal M, Leroi F. 2001. Spoilage Potential and Sensory Profile Associated with Bacteria Isolated from Coldsmoked Salmon. Food res Int 34:797-806.

SNI 01-7265.1-2006 Badan Standarisasi Nasioanal (BSN) 2006. Persyaratan mutu dan keamanan pangan bakso ikan.

SNI. 2009. Penilaian Organoleptik pada Produk Ikan Asap. SNI No. 01-2725.1.2009. Badan Standarisasi Nasional.

Varnam, A. N, and J. P. Sutherland.1995. Meat and Meat Products. Chapman and Hall. London. 